\title{
THE TWO HUNDRED AND FIFTIETH ANNIVERSARY OF CHEMICAL INDUSTRY IN AMERICA
}

By C. A. Browne, New York Sugar Trade Laboratory, New York City

Dr. Bernhard C. Hesse, in his excellent address upon "Our Preparation for After the War" printed in the November I9I 8 issue of THIS JOURNAL, made the very pertinent suggestion that the Fiftieth Anniversary of the American Chemical Society, which comes in 1926 , be celebrated by a Jubilee Volume, which shall give a compact and complete account of what American chemists have done. The suggestion is a most admirable one and should be acted upon immediately. It is only seven years to the anniversary date of our Society and fully this amount of time will be needed for collecting, editing, and printing the material which shall do credit to such a volume.

Some of the readers of Dr. Hesse's address may have wondered, however, why he should date the origin of chemistry in America from the year 1768 . This year antedates the Declaration of Independence and if we are going back to colonial times, as we very properly should, let our Jubilee Volume describe the origins of American chemistry from the very beginning. The writer has collected a considerable amount of material upon the development of chemical industries during the early days of our. country's history and in the present communication wishes to call attention to the first origins of chemistry in America and to the man, who, in point of time, should have the honor of being called the first American chemist.

The importance of colonial manufactures was realized in England at the very beginning of the movement to found American settlements, and it is interesting to know that some of the earliest enterprises in which the English settlers engaged belonged to what are now termed chemical industries. The London Company, the year after they founded the Jamestown Settlement, sent eight Poles and Germans to the new colony to make pitch, tar, glass, and soap-ashes. No sooner were these workmen landed than they began operations, with the result that the settlers soon afterward shipped to London a cargo which consisted of lumber and what Captain Smith called "trials of pitch, tar, glass, frankincense, and soap-ashes." From this small beginning in 1608 we must date the commencement of chemical industries in America. The glass-house used for these trials stood in some woods about a mile from Jamestown. In the words of Dr, J. L. Bishop, "though probably very unpretending in its dimensions and appointments, it was doubtless the first manufactory ever erected in this country."

The scope of industrial activities at Jamestown was rapidly widened. In 1620 Sir Edwin Sandys, treasurer of the London Company, reported that I5O workmen had been sent to set up three iron works, that the efforts to make pitch, tar, potashes, and soap-ashes were being developed, and that the salt works, which had been suffered to go to decay, were restored with hopes of such plenty as not only to serve the needs of the colony but also to supply the great fisheries on the Atlantic Coast. The iron works mentioned in this report were at Falling Creek on the Jamestown River and the salt works at Cape Charles on the Eastern Shore.

Attempts were being made to extend the activities of the colony to lead smelting and to other fields when all industrial efforts were paralyzed by the Indian massacre of 1622 . The iron works, glass-house, and other establishments were not only entirely demolished, but the courage to begin new enterprises which were under contemplation, such as the development of mineral resources, the distillation of walnut oil, the preparation of gums, drugs, dyes, and other plant products, was completely crushed. The Virginia settlers, after the failure of these early enterprises, turned from manufacturing to the more congenial and lucrative pursuit of agriculture for which, after all, the natural resources of the colony were better adapted. More money could be made in growing tobacco than in the uncertainties of glass and iron. The colonists, henceforth, came to depend exclusively upon the Mother Country for their iron, leather, earthenware, and other commodities, to the grief of the historian Beverley who in I 705 complained bitterly of the sad relapse of his countrymen from the self-reliance of the early settlers. This appeal, however, was without effect. Virginia became a colony of planters, and the chemical industries, which the Jamestown settlers had the honor of commencing, were obliged to look elsewhere for a home.

Chemical industries in the New England colonies were destined to run very much the same course as in Virginia. We find the same attention being given to the manufacture of such necessities as iron and salt, the same difficulties from Indian wars in the way of exploiting mineral resources, and the same, although much slower, decay of these industries owingtolack of natural resources. The first development of many important industries, such as those of oil, soap, candles, and distilling, took place in New England as a result of the whaling, fishing, and commercial activities of its early settlers.

As a matter of special interest, in view of present war conditions, mention should be made of the birth of our ammunition industries. On June 6, 1639, the General Court of Massachusetts made a grant of 500 acres of land at Pecoit to Edward Rawson, "so as he goes on with the powder, if the saltpeter comes." The uncertainty of depending upon outside supplies of saltpeter caused this Court to issue in June 1642 the following order for promoting the public safety. In order to raise and produce "such materials amongst us as will perfect the making of gunpowder, the instrumental meanes that all nations lay hould on for their preservation... .every plantation within this Colony shall erect a house in length about 20 or 30 foote, and 20 foote wide within one half year next coming, ... . to make saltpeter from urine of men, beastes, goates, hennes, hogs and horses dung."

Lack of space prevents our touching upon the origin of other chemical industries in New England except as they concern the life of the earliest American chemist.

In the beginning of 1669 , just 250 years ago, Henry Oldenburg, secretary of the newly founded Royal Society, wrote the following words to John Winthrop, Jr., fellow member of the Society, and Governor of the Colony of Connecticut: "Give me leave, I pray, to inquire what chymists you have in your parts and whether they have written anything considerable."

This attempt to determine the names and status of American chemists may be regarded as the prototype of the questionnaire which our Chemical Warfare Service recently sent through the length and breadth of the land. It is not known what answer, if any, Governor Winthrop made to the request of Oldenburg. Probably modesty forbade his replying to the Honorable Secretary that excepting himself there was at that time probably no other man in the American colonies who could claim the title of chemist.

The name of John Winthrop, the younger, is so firmly associated with the political and military history of the English settlements that his services in the field of science and industry have been overlooked. Excepting a few curious-minded antiquarians, probably no chemists of the present generation ever have occasion to refer to the early records of the Royal Society, otherwise Winthrop's contributions to various chemical subjects would have been more frequently mentioned. All American chemists know of Sir Robert Boyle, discoverer of Boyle's law and author 
of "The Skeptical Chymist," yet few of them, probably, are aware of his intimate friendship with Winthrop and of the association of these two men, not only in chemical matters, but in subjects which had a more immediate bearing upon the material and spiritual welfare of the early colonial settlements.

Johı Winthrop ${ }^{1}$ was born at Groton, England, February I2, 1606. After studying at the Free Grammar School at Bury St. Edmunds, he spent several years at Trinity College, Dublin, and then finished by studying law in London, where he was admitted to the bat in 1625 . The next five years were spent in adventure and travel, Padua, Venice, Constantinople, and many other European cities being visited. It was during this period, no doubt, that Winthrop formed an acquaintance with many of those scientists and scholars with whom in after years he corresponded in Latin.

In I630 Winthrop's father sailed for the new colony at Massachusetts Bay and the succeeding year the son followed. Young Winthrop entered immediately into all the activities of his new life. In March I633, he planted a settlement at Agawam, the present Ipswich, but the death of his wife and daughter caused a change in his plans and the following year he sailed for England on an errand in the interest of the colony. It was during this visit that young Winthrop was granted authority by Lords Say and Brook to begin a plantation in Connecticut for which they gave him men and means with an official commission as Governor. Winthrop, who had meantime remarried, sailed again for America and in November I635 built a fort at Saybrook in his future colony.

Winthrop's connection with the Massachusetts Bay Colony did not, however, definitely cease until 1650 , and during this interval he was constantly engaged in many activities of an official and private nature. In June 1638 he obtained permission to set up a salt factory at Ryall-Side, in what is now Beverly, and in I64I he sailed for England to obtain funds and men for the erection of iron works. Among the papers. of Winthrop is an "nteresting memorandum upon "Considerations concerning Ironworks" in which he tells how after making a search for ore in Maine and New Hampshire, he finally decided to locate his iron furnace at Braintree, Mass., at which place the General Court in I644 gave him and his partners a grant of 3000 acres. He obtained the same year a grant to start similar works in the Pequot country, a section which in 1647 was transferred to Connecticut.

In 1646 Winthrop made his home in New London and in 1650 severed his official connection with the Massachusetts Bay Colony, in order to devote his time entirely to the welfare of Connecticut. His interests in the material resources of his colony is shown by an act of the General Assembly for 1651 :

Whereas in this rocky country, among these mountains and rocky hills, there are probabilities of mines of metals, the discovery of which may be of great advantage to the country in raising a staple commodity; and whereas John Winthrop, Esquire, doth intend to be at charges and adventure for the search and discovery of such mines and minerals: for the encouragement thereof, and of any that shall adventure with the said John Winthrop, Esquire, in the said business, it is therefore ordered by the Court that if the said John Winthrop Esquire, shall discover, set upon and maintain such mines of lead, copper, or tin, or any minerals, as antimony, vitriol, black lead, allum, stone-salt, salt springs, or any other the like, within this jurisdiction, and shall set up any work for the digging, washirig, and melting, or any other operation about the said mines or minerals, as the nature thereof requireth, that then the said John Winthrop, Esquire, his heirs, associates, partners or assigns, shall enjoy forever said mines, with the lands, wood, timber, and water within two or three miles of said mines, for the

1 For the main facts in this article pertaining to Winthrop's life use was made of T. F. Water's excellent biography, published by the Ipswich Historical Society. For Winthrop's relations with the Royal Society, Birch's History of the Royal Society, the Proceedings of this Society, and the letters of Winthrop, published in the Massachusetts Historical So ciety's Proceedings, Series I, Vol, XVI, Pp. 206-251, were consulted. necessary carrying on of the works and maintaining of the workmen, and provision of coal for the same.

It is doubtful if a greater or more unlimited monopoly for the production of chemical products was ever granted to a man than this. The unsettled condition of the country and troubles with the Indians (to say nothing of the non-existence of any such mines of wealth) prevented Winthrop from enjoying the slightest part of the fruits of this ambitious program. He did, however, establish salt-works at New London and made plans for the erection of iron works near New Haven, to which place he moved in 1655 .

In order to obtain a Royal Charter for his colony, Winthrop, in the autumn of $I 66 \mathrm{r}$, went again to London, where he resided utrtil the spring of 1663 before his diplomatic errand was finished. It was during this interval that he joined the Royal Society (organized in 1660 ), his name being proposed December I8, $\mathrm{I} 66 \mathrm{I}$, and his admission taking place January $\mathrm{I}, \mathrm{I} 662$. During the fifteen months of his participation in the meetings of the Society he took a most active part in all that was said and done. Winthrop's love for chemical and scientific pursuits had always been strong and he was now able, for the first and only time in his life, to satisfy these tastes by associating with interested and congenial friends.

In the Society meeting for March 5 , Winthrop was appointed to a committee to investigate the refining of gold. On April 23 he gave a demonstration of a self-feeding tin lamp "burning high like a candle" of which a diagram was made and registered. At this same meeting he exhibited a specimen of malleable mineral lead and other samples. On April 30 he exhibited other mineral specimens. On June 25 he was asked to prepare a paper upon pitch and tar. This subject was reported upon July 9, and on July I 6 his completed paper, "Of the Manner of Making Tar and Pitch in New Fingland," was registered in the Proceedings of the Society (Register Book, Vol. I, p. I79). The title and date are important, for it marks the first contribution from an American before a scientific society, and it is a satisfaction for chemists to know that the subject relates to industrial chemistry. In this paper Winthrop describes in detail the method of collecting pitch-pine knots and subjecting them to heat, the tar being recovered by what he calls a distillatio per descensum. Other subjects reported upon by Winthrop during the I662 meetings of the Royal Society related to black lead, the manufacture of potashes, and the exhibition of various mineral and vegetable products.

On January 7,1663 , Winthrop was asked by the Royal Society to undertake an experiment upon brewing beer from maize. The research was a rather elaborate one as we can see from references contained in the minutes of subsequent meetings. Finally on March I I he made his report, presenting the members as a result of his experiments some bottles of beverage which was pronounced to be "a pale, well-tasted, middle beer." In this experiment eight gallons of beer were brewed from about half a bushel of maize.

Winthrop's report upon the brewing of maize was included in a paper upon the "Description, Culture and Use of Maize" which appeared in the Philosophical Transactions of the Society for 1678 (No. I42, pp. 1065-1069). In this paper Winthrop calls attention to the possibility of making syrup and sugar from cornstalks: "A syrup as sweet as sugar may be made of it, as hath been often try'd. And meats sweetened with it have not been distinguished from the like sweetened with sugar. Trial may easily be made, whether it will not be brought to crystallize, or shoot into a saccharine powder, as the juice of the sugar cane." It was over I 50 years before this suggestion of Winthrop was carried out.

Winthrop was asked by the Society to keep some of the beer which he exhibited in order to see how it would stand ageing but this part of the experiment was interrupted by other duties. 
On March i 8 he notified the Society that he was about to return to New England. His final attendance at the meetings was on March 25 when he was given a commission to execute some experiments upon sea-sounding and was provided with apparatus to procure samples of water from the bottom of the ocean. This last commission, owing to defects in the apparatus and the roughness of Winthrop's homeward voyage, could not be carried out.

The chemists whom Winthrop met at the meetings of the Royal Society were among the celebrities of the day and comprised men of every shade of opinion. There were old-time alchemists, such as Elias Ashmole and Kenelm Digby, practical technologists, such as Robert Moray, and skilled experimenters, such as Robert Boyle. It was a transition period between the old order of things and the new, and remnants of old beliefs crept into the meetings on more than one occasion. A smile is provoked now upon reading that at one meeting, after Winthrop had exhibited the tail of a rattlesnake, a doctor who was present took the rattles home "to make some trial of the powder of it," yet the incident is recorded with all seriousness. No mention was afterwards made of the powder's medicinal value.

The short time spent by Winthrop among the members of the Royal Society has been called the happiest period of his life and his return to the wilds of Connecticus, in spite of the desire to see his family again, was no doubt attended with feelings of regret. The separation from the comradeship of the Royal Society was somewhat alleviated, however, by correspondence, although months and years, in some cases, elapsed before mail was delivered. All too frequently the letters, communications, and specimens which Winthrop sent to the Royal Society were lost at sea either from capture by Dutch privateers or from shipwreck. In the same way letters and books sent to Winthrop by his Furopean friends often failed to reach their destination.

The modern chemist, in the comforts of his club or in the fellowship of his society meeting, does not always appreciate the benefits of his position. There is no better way of bringing this truth home than by contrasting these advantages with the desolation of Winthrop's surroundings. We can form some idea of his longing for scientific companionship from a letter which he wrote to Sir Robert Moray from Hartford, September 20, I664.

I had sad and serious thoughts about the unhappinesse of the condition of a Wilderness life so remote from the fountains of learning and noble sciences.... . when I was greatly revived with the speciall favour of your honor's letter. ....

After telling Sir Robert about his attending the surrender of New York by the Dutch to the English the previous August, Winthrop next answers some of his correspondent's questions regarding the industries and mineral resources of Connecticut.

Matters of public concernment have been so many and difficult since I came over and severall occasions preventinge, that though I have had men at work about some preparations for a salt worke, yet could never have tyme to goe to the Sea Side (which is about 60 miles from this place) to make triall of the businesse, but am waiting some good oportunitye for it, of which I may give your honor some account afterwards.

I had a piece of Marcasite, which seemed to containe copper, an Indian brought from up in the country, but there have beene such warres amonge the heathen in these parts that there could be no travelling that way upon such discoveries, but time I hope will give better oportunitys. I heare there is peace like to be made amongst those Indians shortly, which before the Dutch suffered not whilst that land was in their power. I shotild be glad there could be found any minerall matters of reall worth.

I must be bold to crave the favor of my humble service to the President and the gentlemen of the Royall Society.

The difficulties and dangers of prospecting retarded the de- velopment of chemical industries in the early colonies at least a hundred years. In a subsequent letter (August I8, I668) to Sir Robert Moray, Winthrop alludes to this:

I shall not now repeat what was mentioned in former letters except some little about mineralls, though I may be assured that all which were sent came not to your hands. I have been very inquisitive after all sorts of mineralls, which this wildernesse may probably affoard; but indeed the constant warrs, which have continued amongst the Indians since I came last over, hath hindered all progresse in searching out such matters, for some of them which have formerly brought any specimens of that kind were kild in the warr, and others, who pretend to know places of likely appearance, dare not goe up into the country, without strong parties: those places which have beene for present of most hopes for $)$ and $\delta 1$ are best knowne to the Honble. Colonell Nicolls... Better tymes may promote better discoveries, for which we must waite. Those shewes of mineralls, which we have from the Indians, doe only demonstrate that such are in reality in the Country, but they usually bring but small pieces, which are found accidentally in their huntings, sticking in some rock or on the surface of the earth, or the side of some hill, or banke of a river: but they seldom speake of any great quantity where they finde it, nor can they in likelihood meet with a solid veine of good metall, which usually lyeth deepe in the earth, never opened by them, nor have they meanes to do it, therefor cannot know what is in those bowells, except where an earthquake hath shaken downe the side of an hill, or made some rent amonge the rocks....

Concerning the Iron stone of these parts and the Iron works, I forbeare to mention anything againe now about those matters, having written largely formerly, as also concerning lead and something about copper and some considerable expenses bestowed rashly upon trialls of a stone that holdeth (as is supposed) some small quantity of that mettall: as also what trialls have beene made by digging into the earth and through some rocks, in hope of good mettals, of all which I may hope againe to recollect my thoughts about those particulars of which I have formerly written.

Winthrop's faculty for making and holding friends had probably as much to do with the correspondence between him and the members of the Royal Society as a mutual desire to gather knowledge. Wherever this faculty exists it seems always to be accompanied by a certain liberality and tolerance of opiniontraits which, asexemplified in such men as Franklin and Priestley, are usually found to go with a love for science. The harsh, intolerant spirit, which characterized so many New England Puritans, was entirely absent in Winthrop. "I rejoice," wrote Roger Williams, "that youre name is not blurrd, but rather honord, for your prudent and moderate hand in the late Quaker trials amongst us," and again in a letter written to Winthrop the year before his death, "You have bene noted for tendernes towards the bodies and infirmities of poor mortalls. You have bene tender too toward the estates of men in your civill steerage of government and toward the peace of the land, yea, of these wild savages."

The same attachment to Winthrop is shown in the letters of his English and Continental friends. One of the latter, when about to send some works of Glauber and other chemists to Winthrop, wrote to an English acquaintance in quaint German, "Hern Winthrop wolle der Herr meinet wegen hertzlichen grüssen. Ich bin seiner nit vergessen, dencke noch oft an Ihn und bisweilen wünsche Ich mich bey Ihn auff $1 / 2$ oder gantzen tag."

But of all these friends none was more faithful than Henry Oldenburg, who must always rank as the model for a scientific secretary. "You will please to remember," he writes Winthrop, "that we have taken to taske the whole Universe and that we were obliged to doe so by our Dessein,.... We know your ingenuity, experience and veracity, the best qualities of a man and philosopher and we doubt not but you will let us share in the happy fruits and products thereoff. And, since you have now been from us severall years, give us at least a visit by a Philosophicall letter..... The Royal Society, who retains still a particular

1 The alchemistic symbols for silver and mercury. 
respect and kindnesse for you, will receave what shall come from you. ... with no ordinary affection and thankfulnesse."

Oldenburg not only urges Winthrop to contribute papers upon the mineral resources of his colony and upon his new method for manufacturing salt, but he sends him at the same time copies of the Society's transactions with chemical books by Boyle and other authors. He also keeps him posted upon the latest researches which the Society had under way. "Since you went," he writes again, "the Society hath made, among others, the Torricellian Experiment in a glass-tube of 40 feet high which costed much trouble but gave contentment." He then describes with considerable detail another experiment which seemed to contradict Boyle's theory of "the spring and weight of the air."

In every letter Oldenburg pressed his friend to write a book upon the natural resources of New England but the cares of office allowed Winthrop no time for such a project. He longed for leisure and the opportunities for research and study and wished to resign the Governorship but the General Assembly refused to give their consent. In performance of his duties as Governor he attended a meeting of the Colonial Commissioners at Boston in the winter of $1675-1676$, and it was while absent upon this mission that he contracted his final sickness. $\mathrm{He}$ died at Boston, April 6, I676, and was buried in King's Chapel cemetery.

The objection may be raised against the claim that Winthrop was our first American chemist by saying that he was not a professional chemist but only an amateur. Without denying this, it may be said that the same objection would apply to all chemists for the next hundred years after Winthrop's death. They were not chemists by vocation, but by avocation. The great Priestley was not a chemist by profession, but a Unitarian minister.

In support of the claim for Winthrop we have not only his own letters and the records of the Royal Society but we have the testimony of his contemporaries. In a tribute by the colonial poet Benjamin Thompson the dedication is addressed "to the Honourable Dust of that most Charitable Christian, Unbiassed Politician and Unimitable Pyrotechnist, John Winthrope, Esq.: A Member of the Royal Society and Governor of Conecticut Colony in New England, who expired in his Country's Service, April 6, I676."

In this tribute 'Thompson mentions little about Winthrop's political achievements but devotes nearly half the poem to his chemical pursuits.

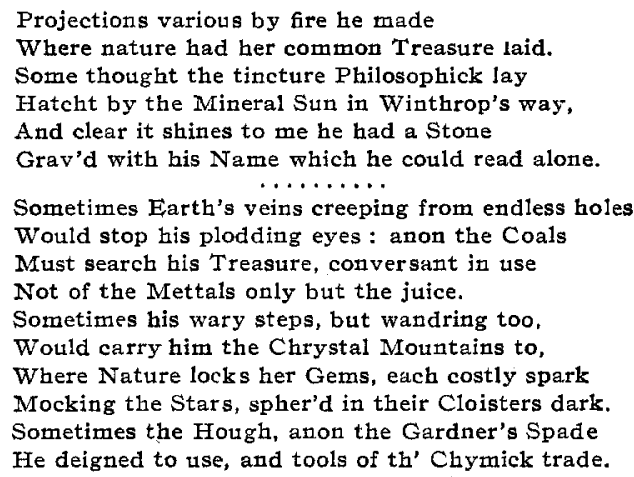

Winthrop's death may be said to mark the close of the first epoch in the history of industrial chemistry in America, the epoch which was mostly devoted to what were called "trials." The future of chemical industries in America was destined to remain neither in Virginia nor in New England. With the founding of another colony by William Penn, six years after Winthrop's death, a new era was to begin when undiscovered mineral resources, of an extent and character hitherto undreamed, were to make the Middle Atlantic Section the future center of chemical industry.

But the period when our ancestors made trials of pitch, tar, glass, salt, powder, and iron ought not to be forgotten and it should be commemorated at the fiftieth anniversary of the american Chemical Socrety. The occasion would be fitting, for it has the sanction of a commemoration in more ways than one.

Winthrop died on April 6, 1676, and on April 6, 1876, exactly two hundred years later to the day, the AMERICAN CHEMrCAL, SocIETY had its birth.

As the origin of our Society dates back to a meeting of chemists about the grave of Priestley, we can celebrate its fiftieth anniversary in no better way than by meeting in Boston in 1926 about the grave of Winthrop, the man who first brought chemistry into the wilderness, who labored to apply his chemical knowledge to the service of his fellowmen, and who, in spite of his own failures, had unbounded faith and confidence in the future.

\section{CHEMICAL MARKETS OF THE WEST INDIES}

By O. P. Hopkins, Washington, D. C.

It is a fact not generally appreciated that the West Indies are second only to Europe as a market for American goods. During the fiscal year rgI 6 these islands imported nearly as much from America as the continenti of South America, two-thirds as much as was taken by all Asia and the East Indian Islands, or seven times the total sold to China. Cuba, of course, takes the bulk of the trade, but some of the other islands are worth-while customers and constantly becoming more attractive; in fact, the opportunities for future.expansion throughout the Archipelago are quite as promising as in any other quarter. The extraordinary natural resources of the islands have not nearly been fully developed.

The wealth of the West Indies lies in agricultural, forest, and mineral products which are exported in the main as crude or partly manufactured materials. Imports, on the other hand, consist of manufactured goods and foodstuffs, of which the United States is the chief source of supply because of favorable location and superior knowledge of the markets.

All of the islands are covered in this article except a few of the very smallest, which have no trade to speak of, and the American possessions, Porto Rico and the Virgin Islands, which are usually included in studies of the American possessions. The table showing the chemical trade as a whole is in each case compiled from the official statistics of the country, while the tables showing the trade with the United States are made up from published statistics of the United States Bureau of Foreign and Domestic Commerce.

\section{CUBA}

Sugar is the principal source of Cuban wealth, followed by tobacco. The elimination of the competition from European beet sugar during the war has 